\title{
MODERN TECHNOLOGIES AND FOREIGN LANGUAGE TEACHING
}

\section{Szerző:}

Tomáš Godiš

Trnava University in Trnava (Slovakia)

\section{Lektorok:}

Orsolya Hegedûs

Constantine the Philosopher

University in Nitra (Slovakia)

Ildikó Pšenáková

Trnava University in Trnava

(Slovakia)

E-mail:

tomasgodis@gmail.com ...és további két anonim lektor

\begin{abstract}
Absztrakt
A modern kommunikációs technológiáknak köszönhetően a nyelvoktatás napjainkban forradalmat él át. Az új kreatív módszertani eljárások, a hallgató oktatási igényeihez való jobb eligazodás vagy a tanítás nagyobb autonómiája csak néhány előny a modern technológiákból. Ezenkívül a nyelvgyakorlatok és az átfogó nyelvi programok vagy alkalmazások különféle online portáljainak köszönhetően a tanárnak számos autentikus tananyag is rendelkezésre áll, amelyek lehetővé teszik számára, hogy hatékonyabban teljesítse az oktatási célokat, reflektáljon a tanulói igényeire, motiválja őket és oktatási potenciáljuk teljes kihasználására késztesse őket. Cikkünkben mélyebben az online nyelvi portálra és az átfogó nyelvi programokra fogunk koncentrálni.
\end{abstract}

Kulcsszavak: E-learning, nyelvi programok, online nyelvportál-portálok, modern technológiák

Diszciplina: pedagógia

\begin{abstract}
Thanks to modern communication technologies, language teaching is experiencing a revolution today. New creative methodological procedures, better orientation to the student's educational needs or greater autonomy of teaching are just some of the benefits that modern technologies bring. Moreover, thanks to various online portals of language exercises and comprehensive language programs or applications, the teacher also has several authentic teaching materials at his disposal, which enables him to more effectively
\end{abstract}


fulfill educational goals, reflect the needs of his students, motivate them and make full use of their educational potential. In our paper, we will focus more deeply on the online language portal and comprehensive language programs.

Keywords: E-learning, language programs, online portals of language exercises, modern technologies

Discipline: pedagogy

Godiš, Tomáš (2021): Modern technologies and foreign language teaching. Mesterséges intelligencia - interdiszciplináris folyóirat, III. évf. 2021/1. szám. 87-100. doi: 10.35406/MI.2021.1.87

The global pandemic and the resulting school closure measure have radically affected (not only) foreign language teaching. This period will go down in school history as the so-called "Homeschooling" - i.e. home elearning of students through information and communication technologies, especially computer programs or applications (e.g. MS Teams, Webex or Skype). Even before the pandemic, integrating communication technologies into teaching was underway, but the pandemic significantly accelerated it. At the same time, both the advantages and disadvantages of these technologies have been revealed. In the teaching process today, we encounter various types of information and communication technologies - they are mainly interactive whiteboards, radio and television equipment, computers and many programs not only for teaching a foreign language. Undoubtedly, the most significant advantages of these electronic means include streamlining the teaching process, clearer communication (using graphs, visualizations, simulations), new teaching methods and procedures, an endless source of information, more autonomous teaching elements, a better reflection of students' educational needs or unrestricted access to authentic language materials (video, audio or reading texts). On the other hand, the integration of modern technologies into education - as already mentioned - also reveals many problems, especially in the form of outdated technical equipment in schools, slow connection to the Internet, which cannot cope with the onslaught of connecting hundreds of computers at once, which reduces the quality of the teaching process.

It should be noted that many students, mainly from the socially weaker sections of society, do not have a computer at all, so they cannot be educated electronically. Therefore, thanks to the 'Renew Europe' program, the European Union has decided to solve this 
problem and invest many millions of euros in digitization - especially in modern technical equipment for schools. The goal is the availability of e-learning for all students. However, the sudden transition to distance teaching also showed shortcomings in the media-didactic competence of teachers. During the transition to distance learning, many teachers had a problem implementing teaching in electronic form and first had to complete various webinars or trainings. For this reason, too, one of the priority goals of universities or educational institutions preparing future teachers must be to educate them in media skills and thus improve their didactic competencies.

\section{Foreign language and modern technologies}

As a grouping of 26 member states (including Slovakia), the European Union is defined as a multicultural environment in which it is necessary to speak more foreign languages. In the territory of the Member States, 440 million people speak 24 official and more than 150 unofficial languages. The English language is undoubtedly considered to be the lingua franca. However, mainly social and economic reasons increasingly require the command of other languages chiefly the economically strongest and culturally most influential countries, and thus German, Spanish, French or Italian. The EU enshrined support for teaching at least two foreign languages in the Lisbon and Barcelona Declarations of the EU Summits in Lisbon (2000) and Barcelona (2002). Based on these declarations, every EU citizen should have access to the teaching of at least two foreign languages (EU Fact Sheets. 2021. online). The EU also supports the teaching of foreign languages financially - through various $\mathrm{Eu}-$ ropean projects of the European Social Fund, but also by building renowned research institutions such as the "European Research Centre for Multilingualism and Language Learning" - (MERCATOR) or the "European Centre for Foreign Languages" (ECML). Both institutions are dedicated, among other things, to the methodology of teaching foreign languages and are behind a unique system for assessing language skills - the "European Framework of Reference for Languages" (CEFR).

Thanks to EU support, many Slovak schools have succeeded in equipping themselves with modern technologies and introducing a certain standard of e-learning. However, modern technologies in the teaching of (not only) foreign languages are not a new phenomenon. Technical means such as interactive whiteboards, radios, data projectors and DVD technology have been used for a long time. These "didactic media" ("diaktische Medien") as they are called by German didactics e.g. J. Roche (2008. p. 246) - they are "bearers and mediators of information in the context of teaching and learning" (Erdmenger 1997. online). Didactic media are thus technical means that enable the teacher to convey new knowledge to students more clearly and effectively and support them in acquiring new information and skills. Therefore, it is possible to say that they are a 
means of support for both the teacher and the student. Moreover, as Kilian points out, "didactic media also positively influence students' concentration or attention, arouse their interest in language as a means of communication and are associated with a higher motivation to learn it" (Kilian 2008. p.21.).

New modern electronic means are increasingly being used to teach foreign languages, namely various online portals of language exercises or complex language programs. These are available thanks to computers, tablets or smartphones. All these portals and programs make it possible to transform traditional teaching into modern teaching gradually. However, the way is not the complete electronization of education but the impenetration of traditional and electronic forms of education. This form is also referred to as "Blended Learning" or "CALL Computer Assisted Language Learning" (Pokrivčáková, 2008. p. 162). However, Didactics Arnold, Kilian, or Roche agree that teaching through didactic media without a concept, meaningful didactic methods, or transparently formulated educational goals does not automatically mean more effective or motivating education for the student. That is also why there is no need to condemn all methods of traditional teaching and, on the other hand, to overestimate the methods of elearning. (Kilian, 2018. p.23). Combining traditional teaching with media (electronic) elements is ideal because it combines the most effective traditional and electronic teaching methods (Bender, 2017. p. 66).
As there is still no relevant didactic handbook dealing with integrating technical means into language teaching, the teacher must rely only on his media competencies and didactic skills in creating such teaching. However, they must take into account the following advantages and disadvantages of both forms of teaching:

\section{Traditional teaching:}

- is limited by place and time - teaching takes place in the premises of the educational institution and in a specific teaching time,

- the teacher cannot (logically) fully satisfy the educational needs of all students, which limits the effectiveness of the teaching process,

- does not allow to make full use of the total educational potential of students - groups can be (in terms of the level of knowledge) heterogeneous - some students are therefore overloaded, while other students are bored with teaching,

- the content of the information provided may also be limited due to the pace of teaching,

- there is little room for autonomous teaching,

- also allows the use of forms of group work or joint project,

- the teacher can intervene at any time during the lesson, and we do not know whether to explain the problematic subject again,

- allows better use of group work as well as cooperative project teaching, 
- the teacher is better able to diagnose students' educational problems and suggest possible solutions,

- is associated with a high level of social integration within the classroom (or educational group).

\section{Teaching through didactic media:}

- teaching moves to virtual space and allows more flexible use of teaching time (e.g. pre-recorded lessons can be watched at virtually any time),

- brings a higher degree of autonomy to education - based on their educational needs, students can manage themselves, e.g. pace of teaching, listen to the recording several times, return to obscure exercises, re-study the teacher's interpretation - students become coresponsible for their language progress,

- thanks to interactive online exercises, students can choose for themselves what type of exercises they want to develop, sometimes they can also choose their content and thus to pay more attention to what they do not understand and to pay less attention to what they already have sufficient control over,

- online exercises are associated with immediate feedback (e.g. in the form of evaluation of elaborated exercises and the level of quality of competencies),

- the teacher can better reflect on the educational needs of individual students students are given the opportunity to make full use of their educational potential,
- allows the teacher to include more creative elements in the teaching (e.g. more electronic exercises or new methodological procedures - didactic methods),

- places high demands on the pedagogical competence of the teacher,

- changes the role of the teacher, who becomes the manager and planner of the lesson,

- allows presenting information and facts in a more transparent way (through graphs, tables or interactive infographics),

- the student is isolated at the screen and does not build complete social contacts and relationships,

- some forms of education are more difficult to use - e.g. group work, joint project.

Despite certain disadvantages, modern technologies in language education are a huge benefit and are simply inseparable from the modern teaching process. In the following chapters of our paper, we will focus on new forms of modern technology in language teaching, namely online portals of language exercises, language training programs and mobile applications.

\section{Online portals of language exercises in foreign language teaching}

In today's language education, in addition to traditional electronic media (radio, television technology, interactive whiteboard or data projector), various online portals of language exercises, language computer programs and mobile applications are also beginning to be used. 
Online language training portals are available via a computer or tablet with an Internet connection. It is a set of isolated interactive exercises whose goal is to fix different language structures. According to Roche, these are tutorials (Roche 2008, p. 246), allowing students to repeat phonetic, grammatical or lexical structures while representing a specific electronic alternative to exercises in a printed textbook or paper form. The most significant difference is in the interactive elements that online exercises offer, allowing users to deal with them according to their own educational needs (for example, choose their type, form, content).

The creators of these portals are experienced didactics and primarily represent a supplement to specific foreign language textbooks. Due to the connection to specific language textbooks (or literature), most such portals are located on publishers' websites. For example, the Hueber publishing house offers the so-called "Lehrwerkservice" (en: textbook service) - the online exercise portal (www.hueber.de). Important portals for teaching German also include those from Klett Publishing (www.vydavatelstvoklett.sk), Langenscheidt (www.langenscheidt.de) or the Goethe Institut (www.goethe.de). As an example, below is a visual of the German exercise online portals from Hueber and Klett (Figure 1).

Online exercise portals are interactive programs that bring a high degree of autonomy to teaching - the student can decide for themselves how much time they need to de-
Figure 1: Hueber and Klett online portal. Source: Net1, Net2

Hueber Portal - Textbook Delfin

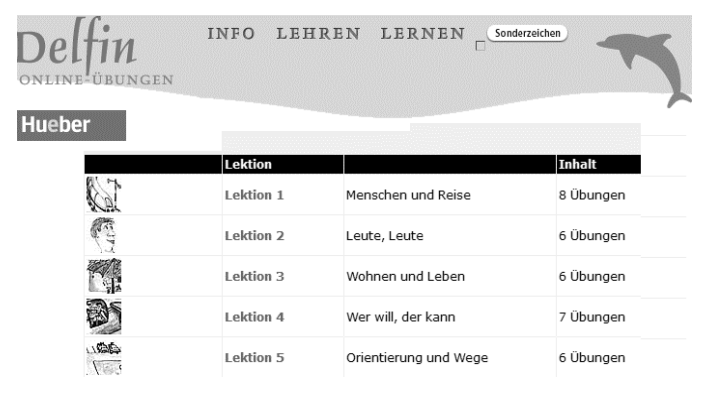

Klett Portal - German language
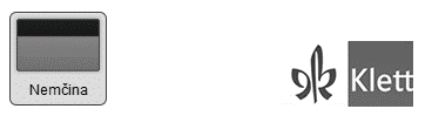

VÝBER UČEBNICE:
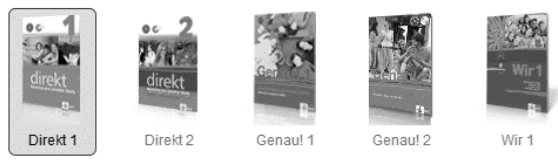

ONLINE CVIĆENIA

VÝBER KAPITOLY

1. Erste Kontakte

ZAHRNÚT̃ TIETO TYPY OTÁZOK:
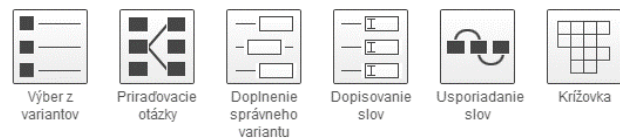

velop an exercise, which exercise they want to return to again and rework, or which exercise they want to skip (because they already understand the curriculum sufficiently). Some portals - such as the Klett portal - even allow the student to choose the topic of the exercises and their form (e.g. assignment, supplementation, crossword, sentence translation exercises - see Fig.1). In this way, the 
student can significantly influence their learning process based on their real educational needs - they thus become co-creators.

The mentioned functions undoubtedly result in numerous advantages of online portals, both for students and teachers. The student will gain more effective teaching and faster language progress with increased motivation to learn the language. The teacher can achieve the educational goals faster and at the same time make full use of the educational potential of the student according to their needs. Students with higher educational performance can enter, e.g. more exercises, and students with less educational performance can, on the contrary, enter less - this does not make students unnecessarily overloaded, and they do not get bored either. At the same time, the teacher will get more time to devote more to those students who do not understand the curriculum sufficiently. They also can take a creative approach to the teaching, integrating new didactic procedures or methods.

After completing the individual exercises on the online portals, the student will receive feedback in evaluating the correctness of the answers and recommending further progress in learning. In our opinion, this type of assessment is very effective because the student immediately knows whether his language skills are sufficient or it is necessary to repeat the curriculum and learn it again. The student can return to the elaborated exercises and do them again. Although online portals usually contain exercises for fixing or repeating lexical, grammatical or phonetic structures of a language (e.g. vocabulary, grammatical phenomena, pronunciation, accent), they often include fun language games or tongue twisters. A significant advantage of some portals is that they are directly linked to educational sites by hyperlinks, where it is possible to find more difficult subjects and have them explained again. One of these websites is the Slovak website www.oskole.sk or the popular German websites www.deutsch.lingolia.com as well as www.mein-deutsch.de.

As already mentioned above, online portals are tutorial (controlled) programs - they do not offer logically consecutive teaching materials but individual monothematic isolated groups of exercises. For this reason, too, teachers must plan them in the teaching process based on given didactic and educational goals. Blended learning is, therefore, a kind of teaching where the teacher becomes a manager, who is required to have a high level of media and didactic competencies, but is also a student's assistant because he/she must teach them not only to work correctly with the portal but also to read feedback results.

Today, there are many portals with online exercises that offer a considerable amount of content. However, many teachers (and sometimes their students) are users and creators of these exercises. Many teachers create materials tailored to their students, whom they know well and know their educational needs. Programs such as Hotpotatoes, Wordwall, Lingofox or, e.g. simulator of creating electronic exercises of the Goethe Institute such as Übungsblätter Selbst gemacht or Suchselmaschine help them to create new 
electronic as well as paper materials (cf. Pšenáková and Hegedűs, 2010) on learning English through mobile devices as well as Pšenáková and Hegedûs (2017) on interactivity in educational materials for language training (Figure 2). In the following lines, we want to introduce the Schuselmaschine and Wordwall programs in more detail, which are also used in didactics courses at the University of Trnava as part of the training of future teachers.

Figure 2: : Programs for creating Hot Potatoes, Wordwall, Suchsel exercises. Sources: Net5, Net7

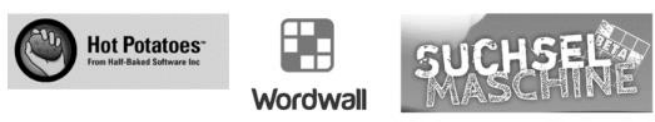

The Suchselmaschine exercise generator is primarily intended for practising vocabulary or word phrases of various language levels. Therefore, it is a simple program that quickly creates crossword puzzles in electronic or printed form. The teacher can create a crossword puzzle in up to four levels of difficulty (easy, medium, hard, and very hard) and insert an unlimited number of terms into it. Thus, it will create exciting crossword puzzles from various thematic areas. However, this generator is used not only by teachers but also by their students, who create crossword puzzles for their classmates and thus practise their language and their media competencies (often in the form of a crosssectional curriculum in computer science or foreign language lessons). The Figure 3 presents the process of creating crossword puzzles in the Suchselmaschine generator. Based on the entered data, the generator creates a crossword (in this case, an eightway).

A similar program for creating exercises is Wordwall, which, unlike Suchselmaschine, however, allows to create at least 45 types of different exercises (e.g., word quiz, memory game, word wheel, find the missing verb, crossword puzzle, anagram, assignment exercises, correct word order exercise, card game and many other types of tasks). The teacher can thus choose the type of exercise that is interesting and motivating for the students (see Fig. 4).

Figure 3: Crossword generator "Suchselmaschine" and a created exercise. Source: Net7
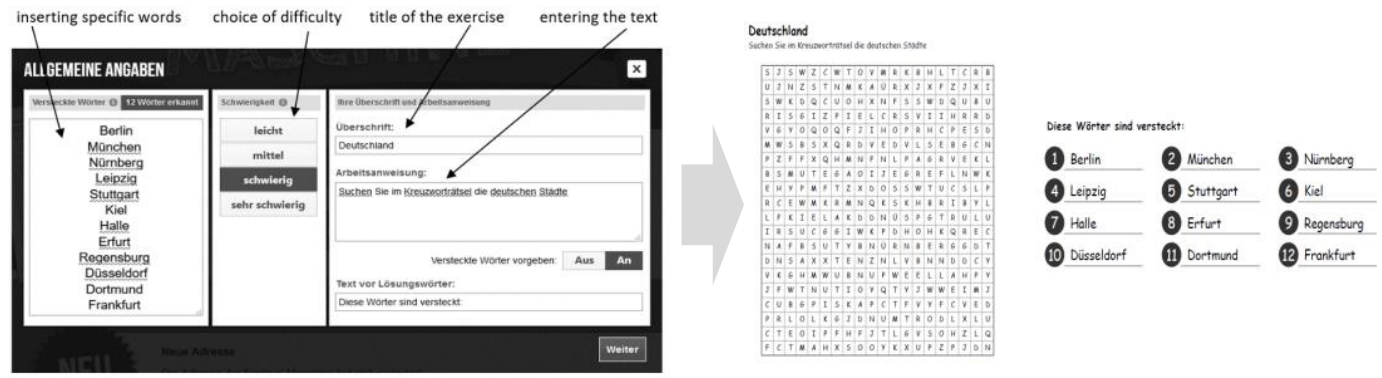
Figure 4: Selection of various exercises in the program Wordwall. Source: Net5

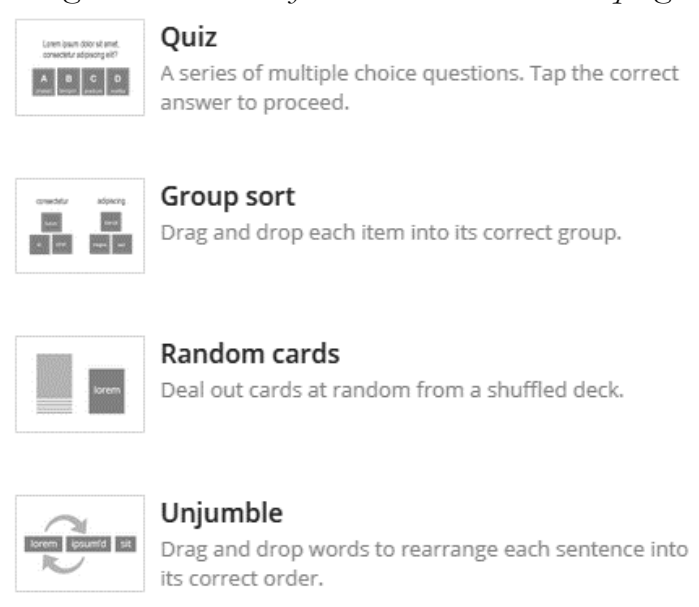

Match up

Drag and drop each keyword next to its definition.

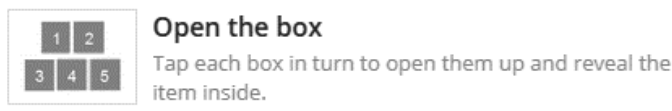

ब. Matching pairs

으 Tap a pair of tiles at a time to reveal if they are a match.

\section{Anagram}

mand vanun Drag the letters into their correct positions to unscramble the word or phrase.
Therefore, it can be stated that this program has a much wider use than the previous one, and it is possible to create exercises not only to repeat the vocabulary but also the grammatical, orthographic or syntactic structure of the language.

If we want to create, e.g. "match up" exercise, it is possible to enter an unlimited number of terms and definitions, which the student has to combine. The teacher can enter both the text of the assignment and the name of the exercise. The process of creating an exercise in the Wordwall program is presented in Fig. 5.

All exercises created in Wordwall are fully electronic, and students can download them via a shared link. All are both interactive and come with feedback. The student will learn immediately after their elaboration whether their solution is correct or incorrect.
Figure 5: Wordwall - generator of "Match up" exercise. Source: Net5 $0: 13$

\begin{tabular}{|c|c|c|c|}
\hline $\begin{array}{c}\text { der } \\
\text { Wasserkocher }\end{array}$ & der Fernseher & das Handy & der Computer \\
\hline $\begin{array}{c}\text { die } \\
\text { Waschmaschine }\end{array}$ & \multicolumn{3}{|c|}{ Damit kann man die Wäsche waschen. } \\
\hline & \multicolumn{3}{|c|}{ Damit kann man Wasser für den Kaffee kochen } \\
\hline & \multicolumn{3}{|c|}{ Damit kann man im Internet surfen. } \\
\hline & \multicolumn{3}{|c|}{ Damit kann man Nachrichten auf RTL ansehen } \\
\hline & Damit kan & man tele & nieren. \\
\hline & & Submit Answe & \\
\hline
\end{tabular}

Programs for creating tailor-made teaching materials are trendy because they help teachers increase students' motivation, reflect their educational needs and, last but not least, make the teaching process more effective. At present, however, complex language programs are also beginning to be established in teaching. We deal with this phenomenon in more detail in the next chapter. 


\section{Complex programs and applications for foreign language teaching}

Today, when teaching languages, we encounter various complex educational computer programs and mobile applications in Slovakia (Fig. 6.). The best known are mainly freeware programs Babbel, Duolingo, Lingvist, Rosetta Stone and others.

Figure 6: Computer and mobile language applications. Source: Net6, Net9, Net10

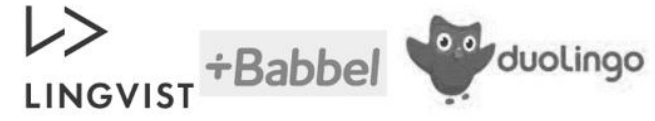

Unlike online language practice portals, these programs and applications are complex and thus contain consecutive teaching units or even entire language courses. Thus, they do not represent a grouping of content-isolated exercises but didactically connected units, which serve not only for the repetition or fixation of the learned curriculum but also for explaining the new curriculum and its practical demonstration. They are primarily intended for self-taught people who want to learn the language, for example, in their free time, but they are also very well used in full-time teaching with a lecturer or teacher. It is the teacher's contribution that multiplies the student's efficiency and success in using these programs and applications. The content of these programs and applications are exercises for the development of receptive and productive language skills - and thus reading, writing, listening and speaking. Thanks to the increasingly modern technology of computers or mobile phones, it is also possible to further develop the speaking skill, which was limited by the microphone quality in the programs and was not given sufficient attention.

The structure of complex programs and mobile applications is strictly logical, clear and easy to navigate. Some applications and programs are structured like a classic strategy computer game. The Duolingo application, for example, has such a structure (see Fig. 7). Its content is divided into several units (from the least to the most demanding), representing certain language levels. To get to a higher level, they must achieve a specific point score in the lower level; otherwise, the program will not move them to a higher level. The aim is to achieve the highest possible language level and thus achieve the best possible knowledge of the language. Just as in the game, its user collects coins for individual completed tasks, the user of this language program gets points that place him in the order of the most effective (or fastest) learning users. We evaluate this motivating element very positively, as it supports healthy competition among students. A crucial part of this program is also feedback in the form of evaluation of completed tasks. It can be defined as multilevel - it follows each item in the exercise, after each exercise, after each lesson and finally after each language level (see Fig. 7). Thus, the student knows precisely whether he/she masters the subject matter sufficiently or has to repeat it. Part of the feedback is also the so-called "Ladders of 
Figure 7: Program Duolingo - structure and evaluation. Source: Net6

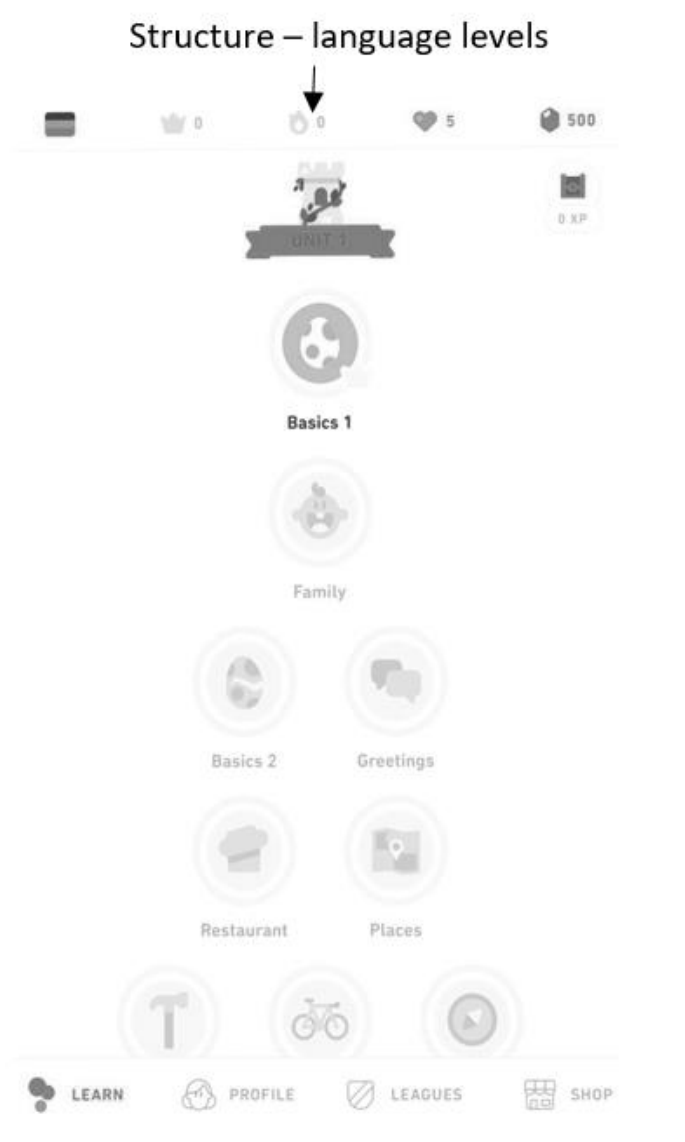

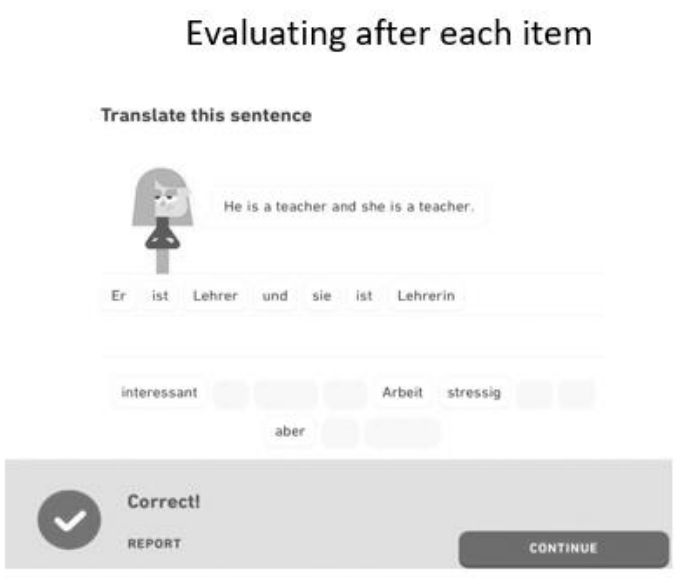

Evaluating after the lesson

Lesson

complete!

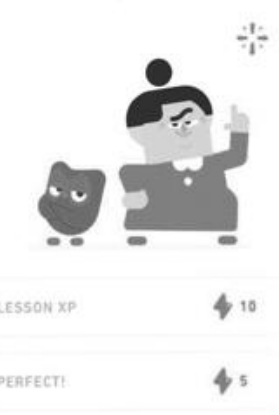

success". This "ladder" records which three students are the most active, achieve the best results, progress the fastest, have the most progressive exercises, the minor errors or the percentage of success in the teaching process within the defined class. Intentionally it is not given to lower-ranking students so that they do not feel demotivated.
The individual levels with tasks are coherent - they represent monothematic units (e.g. family, work, travel, shopping, media) and include relevant grammar. Duolingo also offers students so-called grammar cards - and therefore cards with an explanation of the practised curriculum. If the student does not complete the task correctly or gets few points, 
the program will allow them to re-study the written explanation of the grammatical phenomenon. The disadvantage is that several examples are missing, and there is a risk that, despite studying, the student may not understand the material correctly. For this reason, too, the effectiveness of teaching without interpretation and guidance by teachers is questionable. The teacher has essential functions, apart from a social one, also an explanatory one. If the student does not understand the material, the teacher can explain it in another way to make them understand it as best as possible. However, the teacher must know the student's learning style as well as his intellectual characteristics. Diagnosis of a student within the educational process is one of the essential skills of a teacher, and current language programs do not have this skill.

We consider the danger of insufficient or incorrect (inaccurate) understanding of various grammatical phenomena and lexical elements of the language to be the biggest problem of electronic educational programs. We gained this experience during practical training at language schools, where applicants often come after having completed a course for self-study. It is challenging for a teacher to wean away from students misunderstandings and to teach their curriculum correctly. Misunderstanding grammatical phenomena and their subsequent learning are very frustrating from the student's point of view. A typical example from the German language is modal verbs in the perfect (in the compound past tense). Modal verbs are always used as auxiliary verbs in the perfect infinitive form (e.g., Ich habe ins Kino gehen dürfen.). Unfortunately, very little space is devoted to this phenomenon in electronic programs, and students often learn simply that even a modal verb (as well as any full verb) must stand in the sentence in the form of a participle of the past (Partizip II.), which is a mistake (e.g., Ich habe ins Kino gehen gedurft.) This is just one example of a frequent error, but unfortunately, in reality, we encounter many others. Moreover, for this reason, we are convinced that the explanation of the material by the teacher is necessary for the process of teaching the language - the program (however good it may be) is not fully capable, in our opinion. Therefore, the teacher is an irreplaceable component of the teaching process, and their contribution can increase the effectiveness of the educational program.

\section{Conclusion}

The aim of online exercise portals and comprehensive educational programs or mobile applications is to achieve the highest possible effectiveness of language education. Despite some disadvantages, these electronic means of teaching foreign languages bring huge advantages. Let us mention, e.g. unlimited source of information, amount of authentic materials (texts, videos, listening), new methodological procedures, a better reflection of students' educational needs and educational potential, increased student motivation (compared to traditional teaching), 
higher autonomy of teaching, creative approach by the teacher, faster fulfilment of educational goals and, last but not least, more efficient and better teaching. The teacher has a central role in teaching with integrated modern communication technologies. It is he/she who must organize or plan the teaching well and respect the defined educational goals, the language level of the students, their educational needs, learning style or educational potential. Doing so requires excellent didactic or media competencies. Due to these increasing demands on the teaching profession, universities and educational institutions must prepare their students for future careers in both the didactic and media fields.

\section{References}

Arnold, P., Kilian, L., Thillosen, A., Zimmer, G. (2018). Handbuch E-Learning. Bertelsmann Verlag. Bielefeld Bender, I. (2017). Mediendidaktik Potenziale,Szenarien und Formate der digitalisierten Lehre. online. (Downloaded: 2.5.2021). Web: https://www.unirostock.de/storages/unirostock/UniHome/Weiterbildung/KOS MOS/Mediendidaktik.pdf

Erdmenger, M. (1997). Medien im Fremdsprachunterricht, Hardware, Software und Methodik. TU - Braunschweig.

Braunschweig. (Downloaded: 12.5.2021). Web: https://publikationsserver.tu- braunschweig.de/receive/dbbs_mods_00 001158

Európsky parlament (2021). Informačné listy jasyková politika EU. (Downloaded 12.5.2021). Web: https://www.europarl.europa.eu > FTU_3.6.6.pdf

Lehner, M. (2019). Didaktik. Haupt Verlag. Bern.

Net1. Downloaded: 20.06.2021. Web: www.hueber.de

Net2. Downloaded: 20.06.2021. Web: www.vydavatelstvoklett.sk

Net3. Downloaded: 20.06.2021. Web: www.goethe.de

Net4. Downloaded: 20.06.2021. Web: www.oskole.sk

Net5. Downloaded: 20.06.2021. Web: https://wordwall.net/

Net6. Downloaded: 20.06.2021. Web: www.duolingo.com

Net7. Downloaded: 20.06.2021. Web: www.suchsel.bastelmaschine.de

Net8. Downloaded: 20.06.2021. Web: https://hotpot.uvic.ca/

Net9. Downloaded: 20.06.2021. Web: www.babbel.com

Net10. Downloaded: 20.06.2021. Web: www.lingvist.com,

Pokrivčákova, (2008). S. et al. Inovácie a trendy vo vyučovani cudzích jazykov u riakov mladšieho školského veku. Univerzita Konštantína Filozofa, Nitra

Pšenáková, I. and Hegedűs, O. (2010). Let's learn English through Molibe Phones. Romanian Journal of Education, 1/1, 43-48. 
Pšenáková, I. and Hegedűs, O. (2017).

Interactivity in educational materials for

language training. Módszertani közlöny, 7/1, 219-228.
Röche, J. (2008). Fremdsprachenerwerb Fremdsprachendidaktik. Narr-Francke Attempto Verlag. Tübingen 